\section{Ethephon Foliar Sprays Prevent Premature Flowering of Tissue Culture-propagated Streptocarpus Hybrids}

\author{
Christopher J. Currey ${ }^{1,3}$ and Nicholas J. Flax ${ }^{2}$
}

ADDITIONAL INDEX WORDS. ethylene, floriculture, flower abortion, gesneriad, pinching, potted plant

Summary. Our objective was to quantify foliar ethephon application effects on flowering and growth of several streptocarpus (Streptocarpus $\times$ bybridus) cultivars. 'Ladyslippers Blue Halo', 'Ladyslippers Deep Blue Vein', and 'Ladyslippers Red Rose' streptocarpus were planted in 6-inch containers filled with a soilless substrate. Foliar spray applications of solutions containing $0,125,250,500$, or $1000 \mathrm{mg} \cdot \mathrm{L}^{-1}$ ethephon were applied either 2 weeks after planting (one application) or 2 and 4 weeks after planting (two applications). After 13 weeks, the total number of inflorescences was recorded and the growth index (GI) and time to flower were calculated. The efficacy of ethephon sprays depended on the concentration, number of applications, and cultivar. A single application of 250 to $1000 \mathrm{mg} \cdot \mathrm{L}^{-1}$ ethephon delayed flowering of 'Ladyslipper Deep Blue Vein' by 9 to 27 days, whereas one application of $1000 \mathrm{mg} \cdot \mathrm{L}^{-1}$ applied to 'Ladyslipper Red Rose' delayed flowering by 9 days. Similarly, two applications of any ethephon concentration delayed flowering of 'Ladyslipper Deep Blue Vein' by up to 37 days, while flowering of 'Ladyslipper Red Rose' was delayed by 17 days when $1000 \mathrm{mg} \cdot \mathrm{L}^{-1}$ was applied. The GI of 'Ladyslipper Deep Blue' and 'Ladyslipper Red Rose' was unaffected by ethephon and, while the GI of 'Ladyslipper Blue Halo' was smaller than untreated plants when one or two applications of 500 or $1000 \mathrm{mg} \cdot \mathrm{L}^{-1}$ ethephon was applied; these smaller plants were still of marketable size and quality. We conclude that ethephon may be used to delay flowering and reduce the number of inflorescences formed before finishing with minimal impact on finished plant size.

$\mathrm{T}$ he genus Streptocarpus contains $\approx 130$ species (Hilliard and Burtt, 1971; Möller and Cronk, 2001). Hybrid streptocarpus, commonly called streptocarpus or cape primrose, are the most widely cultivated plants in the genus (Moore, 1957). Streptocarpus are flowering potted plants that grow and flower freely in interior or shaded outdoor areas. Leaf cuttings are commonly used by hobbyist growers or collectors (Ebert and Ebert, 1984), but commercial streptocarpus propagation requires a technique that produces more plants in a shorter time period. Modern streptocarpus cultivars are traditionally produced using $\mathrm{F}_{1}$ hybrid seed (Dole and Wilkins,

Department of Horticulture, Iowa State University, 127 Horticulture Hall, Ames, IA 50011

We gratefully acknowledge Peter Lawlor for greenhouse assistance, Kellie Walters for assistance in collecting data, the Henry F. Michell Co. for plant material, and Fine Americas, Inc., for the plant growth regulator. The use of trade names in this publication does not imply endorsement by Iowa State University of products named nor criticism of similar ones not mentioned.

${ }^{1}$ Assistant professor

${ }^{2}$ Former undergraduate research assistant

${ }^{3}$ Corresponding author. E-mail: ccurrey@iastate.edu.
2005). Additionally, streptocarpus do not require an environmental stimulus such as daylength (photoperiod) or cool temperatures (vernalization) for flower induction and development. The new 'Ladyslippers' streptocarpus series are propagated using tissue culture (Uhl, 2012). While these plants produce showy finished flowering plants, they regularly flower prematurely (i.e., while still in the liner tray) during greenhouse production, requiring hand labor to remove inflorescences.

Ethephon is a plant growth regulator (PGR) that is commonly applied as a foliar spray (Whipker et al., $2011 \mathrm{~b}$ ). When absorbed by plant tissue, the change in tissue $\mathrm{pH}$ causes ethylene gas to be generated within plant cells (Barrett, 2001). As a PGR, ethephon has several effects when applied to containerized ornamental crops (Barrett, 2001; Whipker et al., $2011 b)$. Ethephon may act as a plant growth retardant and minimize stem elongation by reorienting microfibril orientation in cell walls; this causes cells to expand laterally and minimize elongation, which restricts stem height or length. Additionally, ethephon may be employed to increase branching in crops by increasing the ratio of ethylene : auxin, which diminishes apical dominance and releases axillary buds, resulting in enhanced lateral branch development. However, one of the most common uses of ethephon is to delay flowering for vegetatively propagated ornamental flowering crops (Dole and Wilkins, 2005). Flowering delay of vegetatively propagated material is generally desirable to extend the vegetative phase of production (i.e., growth of leaves) to increase the size or "bulk up" a containerized crop and reduce the disease pressure posed by senesced flowers.

We have found no published information on effective concentrations of ethephon for foliar spray applications on streptocarpus to inhibit or delay flowering. The objective of our experiment was to quantify the impact of foliar ethephon applications on the growth and flowering of tissue culture-propagated 'Ladyslipper' streptocarpus.

\section{Materials and methods}

On 25 Sept. 2013, 'Ladyslippers Blue Halo', 'Ladyslippers Deep Blue Vein', and 'Ladyslippers Red Rose' streptocarpus rooted liners in 96-cell trays were received from a commercial supplier. The following day, liners were planted in 6-inchdiameter plastic containers [87.26 $\mathrm{inch}^{3}$ volume (Landmark Plastic Corp., Akron, $\mathrm{OH})$ ] filled with a soilless substrate (Sunshine Mix \#l; Sun Gro Horticulture, Agawam, MA). Plants were grown in a glass-glazed greenhouse with fog cooling, radiant hotwater heating, and retractable shade curtains controlled by an environmental computer (Argus Control Systems,

\begin{tabular}{llll}
\hline $\begin{array}{l}\text { Units } \\
\text { To convert U.S. to SI, } \\
\text { multiply by }\end{array}$ & U.S. unit & SI unit & $\begin{array}{l}\text { To convert SI to U.S., } \\
\text { multiply by }\end{array}$ \\
\hline 0.0929 & $\mathrm{ft}^{2}$ & $\mathrm{~m}^{2}$ & 10.7639 \\
0.4075 & $\mathrm{gal}^{\mathrm{N}} 100 \mathrm{ft}^{2}$ & $\mathrm{~L} \cdot \mathrm{m}^{-2}$ & 2.4542 \\
16.3871 & $\mathrm{inch}^{3}$ & $\mathrm{~cm}^{3}$ & 0.0610 \\
1 & $\mathrm{ppm}$ & $\mathrm{mg} \cdot \mathrm{L}^{-1}$ & 1 \\
$\left({ }^{\circ} \mathrm{F}-32\right) \div 1.8$ & ${ }^{\circ} \mathrm{F}$ & ${ }^{\circ} \mathrm{C}$ & $\left({ }^{\circ} \mathrm{C} \times 1.8\right)+32$
\end{tabular}


Surrey, BC, Canada). The day and night greenhouse air temperature set points were 23 and $19{ }^{\circ} \mathrm{C}$, respectively. A 16-h photoperiod (0600 to 2200 HR) consisting of natural daylengths with day-extension lighting was provided. High-pressure sodium lamps delivered a supplemental photosynthetic photon flux of $191 \pm 27 \mu \mathrm{mol} \cdot \mathrm{m}^{-2} \cdot \mathrm{s}^{-1}$ at plant height [as measured with a quantum sensor (LI-190 SB; LI-COR Biosciences, Lincoln, NE)] to maintain a target daily light integral of $\approx 12 \mathrm{~mol} \cdot \mathrm{m}^{-2} \cdot \mathrm{d}^{-1}$. Plants were irrigated as needed with water supplemented with a blend of water-soluble fertilizers $[50$ and 100 $\mathrm{mg} \cdot \mathrm{L}^{-1}$ nitrogen provided from $21 \mathrm{~N}-$ $2.2 \mathrm{P}-16.6 \mathrm{~K}$ and $15 \mathrm{~N}-2.2 \mathrm{P}-12.5 \mathrm{~K}$, respectively (Everris NA Inc., Marysville, $\mathrm{OH})$ ] to provide the following (in milligrams per liter): 150 nitrogen, 8.6 phosphorous, 92.2 potassium, $33.3 \mathrm{cal}-$ cium, 13.3 magnesium, 0.75 iron, 0.4 manganese and zinc, 0.2 copper and boron, and 0.5 molybdenum. PourThru leachate extractions (Whipker et al., 201 la) were performed to monitor substrate $\mathrm{pH}$ and electrical conductivity to ensure values were within the ranges acceptable for streptocarpus production (Cavins et al., 2000).

Ethephon treatments commenced 2 weeks after planting. Foliar applications of solutions containing 0 (control) $125,250,500$, or 1000 $\mathrm{mg} \cdot \mathrm{L}^{-1}$ ethephon (Collate; Fine Americas, Walnut Creek, CA) were applied at a rate of $0.5 \mathrm{gal} / 100 \mathrm{ft}^{2}$ to 10 plants of each cultivar, either 2 weeks (single application), or 2 and 4 weeks after planting (two applications).

The time to flower from planting was calculated as the number of days from transplanting until the first flower on a plant opened, and the total number of inflorescences each plant produced was recorded throughout the study. The recommended production time for 'Ladyslippers' streptocarpus is 12 to 14 weeks (Uhl, 2012); therefore, we collected final data 13 weeks after planting. Plant height from the surface of the substrate to the tallest growing point and the widths at the widest point and $90^{\circ}$ from the widest point were recorded. These measurements were used to calculate the GI $(\mathrm{GI}=$ \{plant height $+[$ (diameter $1+$ diameter 2)/2]\}/2), an integrated measurement of plant size (Jeong et al., 2009; Krug et al., 2010).

The experiment was conducted in a completely randomized design with 10 replications (individual plants) for each treatment. Regression analyses across ethephon concentrations within application and pairwise comparisons between all treatments using Tukey's honestly significant difference test at $P \leq 0.05$ were performed using SPSS (version 21.0; IBM Corp., Armonk, NY).

\section{Results and discussion}

Ethephon concentration and application number interacted to affect time to flower, number of inflorescences, and GI of cultivars differently (Tables 1-3). Ethephon delayed flowering for all three streptocarpus cultivars, but the effectiveness varied among cultivars with concentration and number of applications (Table 1). A single application of 500 or $1000 \mathrm{mg} \cdot \mathrm{L}^{-1}$ ethephon delayed flowering of 'Ladyslipper Blue Halo' by 18 or $26 \mathrm{~d}$, respectively, compared with untreated control plants, while 250 to $1000 \mathrm{mg} \cdot \mathrm{L}^{-1}$ ethephon applied twice delayed flowering by 20 to $39 \mathrm{~d}\left(R^{2}=0.70\right)$.

Table 1. Time to flower of 'Ladyslipper Blue Halo', 'Ladyslipper Deep Blue', and 'Ladyslipper Red Rose' streptocarpus treated with foliar sprays of water (control) or solutions containing $125,250,500$, or $1000 \mathrm{mg} \cdot \mathrm{L}^{-1}(\mathrm{ppm})$ ethephon applied 2 weeks after transplanting (one application) or 2 and 4 weeks after transplanting (two applications).

\begin{tabular}{lcccc}
\hline $\begin{array}{l}\text { Applications } \\
\text { (no.) }\end{array}$ & $\begin{array}{c}\text { Ethephon } \\
\text { concn }\left(\mathbf{m g} \cdot \mathbf{L}^{-1}\right)\end{array}$ & $\begin{array}{c}\text { Time to flower }(\mathbf{d}) \\
\text { 'Ladyslipper } \\
\text { Blue Halo' }\end{array}$ & $\begin{array}{c}\text { 'Ladyslipper Deep } \\
\text { Blue Vein' }\end{array}$ & $\begin{array}{c}\text { 'Ladyslipper } \\
\text { Red Rose' }\end{array}$ \\
\hline Control & 0 & $31 \mathrm{e}^{\mathrm{z}}$ & $29 \mathrm{f}$ & $34 \mathrm{bc}$ \\
1 & 125 & $36 \mathrm{de}$ & $39 \mathrm{ef}$ & $29 \mathrm{c}$ \\
& 250 & $42 \mathrm{cde}$ & $41 \mathrm{de}$ & $34 \mathrm{bc}$ \\
& 500 & $49 \mathrm{bcd}$ & $50 \mathrm{~cd}$ & $39 \mathrm{abc}$ \\
& 1000 & $57 \mathrm{~b}$ & $56 \mathrm{bc}$ & $44 \mathrm{abc}$ \\
& Significance $\left(R^{2}\right)$ & $\mathrm{Q}^{* * *}(0.57)$ & $\mathrm{Q}^{* * *}(0.59)$ & $\mathrm{Q}^{* *}(0.16)$ \\
& 125 & $38 \mathrm{de}$ & $42 \mathrm{de}$ & $37 \mathrm{abc}$ \\
& 250 & $51 \mathrm{bc}$ & $50 \mathrm{~cd}$ & $41 \mathrm{abc}$ \\
& 500 & $57 \mathrm{ab}$ & $63 \mathrm{bb}$ & $49 \mathrm{ab}$ \\
& 1000 & $70 \mathrm{a}$ & $68 \mathrm{a}$ & $51 \mathrm{a}$ \\
& Significance $\left(R^{2}\right)$ & $\mathrm{Q}^{* * *}(0.70)$ & $\mathrm{Q}^{* * *}(0.82)$ & $\mathrm{Q}^{* * *}(0.24)$ \\
\hline
\end{tabular}

${ }^{2}$ Within-column means followed by different letters are significantly different by Tukey's honestly significant difference test at $P \leq 0.05$.

Significance quadratic $(\mathrm{Q})$ regression across ethephon concentrations within number of application. $* *, * *$ Significant at $P \leq 0.01$ or 0.001 , respectively.

Table 2. Number of inflorescences 13 weeks after transplanting 'Ladyslipper Blue Halo', 'Ladyslipper Deep Blue', and 'Ladyslipper Red Rose' streptocarpus treated with foliar sprays of water (control) or solutions containing 125, 250, 500 , or $1000 \mathrm{mg} \cdot \mathrm{L}^{-1}(\mathrm{ppm})$ ethephon applied 2 weeks after transplanting (one application) or 2 and 4 weeks after transplanting (two applications).

\begin{tabular}{lcccc}
\hline \multirow{2}{*}{$\begin{array}{l}\text { Applications } \\
\text { (no.) }\end{array}$} & $\begin{array}{c}\text { Ethephon } \\
\text { concn }\left(\mathbf{m g} \cdot \mathbf{L}^{-1}\right)\end{array}$ & $\begin{array}{c}\text { 'Ladyslipper } \\
\text { Blue Halo' }\end{array}$ & $\begin{array}{c}\text { 'Ladyslipper } \\
\text { Deep Blue Vein' }\end{array}$ & $\begin{array}{c}\text { 'Ladyslipper } \\
\text { Red Rose' }\end{array}$ \\
\hline Control & 0 & $29 \mathrm{a}^{\mathrm{z}}$ & $14 \mathrm{ab}$ & $20 \mathrm{abc}$ \\
1 & 125 & $21 \mathrm{~b}$ & $15 \mathrm{a}$ & $25 \mathrm{a}$ \\
& 250 & $22 \mathrm{ab}$ & $14 \mathrm{ab}$ & $22 \mathrm{a}$ \\
& 500 & $16 \mathrm{bc}$ & $13 \mathrm{ab}$ & $19 \mathrm{abc}$ \\
& 1,000 & $8 \mathrm{de}$ & $11 \mathrm{ab}$ & $18 \mathrm{abc}$ \\
2 & Significance $\left(R^{2}\right)$ & $\mathrm{Q}^{* * *}(0.60)$ & $\mathrm{L}^{*}(0.09)$ & $\mathrm{NS}$ \\
& 125 & $19 \mathrm{bc}$ & $15 \mathrm{a}$ & $19 \mathrm{abc}$ \\
& 250 & $15 \mathrm{bcd}$ & $11 \mathrm{abc}$ & $21 \mathrm{ab}$ \\
& 500 & $12 \mathrm{~cd}$ & $9 \mathrm{bc}$ & $11 \mathrm{c}$ \\
& 1,000 & $4 \mathrm{e}$ & $5 \mathrm{c}$ & $12 \mathrm{bc}$ \\
& Significance $\left(R^{2}\right)$ & $\mathrm{Q}^{* * *}(0.69)$ & $\mathrm{Q}^{* * *}(0.4 \mathrm{l})$ & $\mathrm{Q}^{* *}(0.18)$ \\
\hline
\end{tabular}

${ }^{2}$ Within-column means followed by different letters are significantly different by Tukey's honestly significant difference test at $P \leq 0.05$

Significance of linear $(\mathrm{L})$ or quadratic $(\mathrm{Q})$ regression across ethephon concentrations within number of application. NS, ${ }^{*},{ }^{* *},{ }^{* * *}$ Nonsignificant or significant at $P \leq 0.05,0.01$, or 0.001 , respectively. 
Table 3. Growth index (GI) 13 weeks after planting of 'Ladyslipper Blue Halo' streptocarpus treated with foliar sprays of water (control) or solutions containing $125,250,500$, or $1000 \mathrm{mg} \cdot \mathrm{L}^{-1}(\mathrm{ppm})$ ethephon applied 2 weeks after transplanting (one application) or 2 and 4 weeks after transplanting (two applications).

\begin{tabular}{lcc}
\hline & & GI $^{\mathbf{z}}$ \\
\hline Applications (no.) & Ethephon concn $\left(\mathbf{m g} \cdot \mathbf{L}^{-1}\right)$ & $19.8 \mathrm{a}^{\mathrm{y}}$ \\
1 & 0 & $17.5 \mathrm{abc}$ \\
& 125 & $19.0 \mathrm{ab}$ \\
& 250 & $17.3 \mathrm{bc}$ \\
& 500 & $16.9 \mathrm{bc}$ \\
& 1,000 & $\mathrm{Q}^{* * *}(0.23)$ \\
2 & Significance $\left(R^{2}\right)$ & $19.4 \mathrm{ab}$ \\
& 125 & $18.2 \mathrm{ab}$ \\
& 250 & $17.3 \mathrm{bc}$ \\
& 500 & $15.5 \mathrm{c}$ \\
& 1,000 & $\mathrm{Q}^{* * *}(0.49)$ \\
\hline
\end{tabular}

${ }^{z}\{$ Plant height $+[($ diameter $1+$ diameter 2$) / 2]\} / 2$.

'Within-column means followed by different letters are significantly different by Tukey's honestly significant difference test at $P \leq 0.05$.

Significance of linear $(\mathrm{L})$ or quadratic $(\mathrm{Q})$ regression across ethephon concentrations within number of application. $* * *$ Significant at $P \leq 0.001$.

Similarly, 250 to $1000 \mathrm{mg} \cdot \mathrm{L}^{-1}$ ethephon applied once delayed flowering of 'Ladyslipper Deep Blue Vein' by 11 to $27 \mathrm{~d}$, while all concentrations of ethephon applied twice delayed flowering by up to $39 \mathrm{~d}$, compared with untreated plants. Flowering of 'Ladyslipper Red Rose' was delayed by $17 \mathrm{~d}$, compared with control plants, when $1000 \mathrm{mg} \cdot \mathrm{L}^{-1}$ ethephon was applied twice. In addition to a diminished delay in time to flower for 'Ladyslipper Red Rose' in response to ethephon application when compared with the cultivars, the $R^{2}$ values were also lower $(0.16$ and 0.24$)$ for regression analyses than the other cultivars $(0.57$ to 0.82$)$.

Ethephon is used to delay flowering for other containerized flowering plants, including herbaceous perennials (Glady et al., 2007; Hayashi et al., 2001) and annuals (Starman and Williams, 2000; Starman et al., 2004). However, the degree of activity of ethephon depends on the species being treated, the number of applications, and concentration of ethephon solutions. For example, eight different species of containerized herbaceous perennials were treated one, two, or three times with foliar sprays containing 500 or $1000 \mathrm{mg} \cdot \mathrm{L}^{-1}$ ethephon (Hayashi et al., 2001). Applying three foliar sprays of $1000 \mathrm{mg} \cdot \mathrm{L}^{-1}$ ethephon delayed flowering of common yarrow (Achillea millefolium 'Weser River Sandstone'), purple coneflower (Echinacea purpurea 'Bravado'), bee balm
(Monarda didyma 'Blue Stocking'), and false dragonhead (Physostegia virginiana 'Summer Snow') by $2 \mathrm{~d}$ (common yarrow) to $9 \mathrm{~d}$ (false dragonhead). Alternatively, ethephon had no effect on time to flower of threadleaf coreopsis (Coreopsis verticillata 'Moonbeam'), shasta daisy (Leucanthemum $\times$ superbum 'Thomas Killen'), spike gayfeather (Liatris spicata 'Kobold'), and garden phlox (Phlox paniculata 'Mt. Fuji'). Glady et al. (2007) also reported that the efficacy of ethephon sprays applied to stock plants of herbaceous perennials varied among the species treated. Biweekly applications of foliar sprays of $600 \mathrm{mg} \cdot \mathrm{L}^{-1}$ ethephon or weekly sprays of $400 \mathrm{mg} \cdot \mathrm{L}^{-1}$ ethephon diminished flowering for threadleaf coreopsis and long-leaf speedwell (Veronica longifolia 'Sunny Border Blue'), whereas flowering of carnation (Dianthus caryophyllus 'Cinnamon Red Hots') was unaffected by ethephon.

Ethephon affected the number of inflorescences for all three cultivars of streptocarpus in this experiment ( $\mathrm{Ta}-$ ble 2). Compared with untreated control plants, 125 to $1000 \mathrm{mg} \cdot \mathrm{L}^{-1}$ ethephon applied once or twice resulted in $24 \%$ to $87 \%$ ( 7 to 25 inflorescences) fewer inflorescences of 'Ladyslipper Blue Halo', whereas two applications of $1000 \mathrm{mg} \cdot \mathrm{L}^{-1}$ ethephon to 'Ladyslipper Deep Blue Vein' caused 39\% (nine inflorescences) fewer inflorescences to form. While there was a significant quadratic relationship between the concentration of ethephon when two applications were made to 'Ladyslipper Red Rose', the $R^{2}$ was low $(0.18)$ and there were no significant differences in the number of inflorescences of ethephon-treated plants compared with untreated plants.

Starman et al. (2004) applied foliar sprays containing 500 or 1000 $\mathrm{mg} \cdot \mathrm{L}^{-1}$ ethephon to 27 different vegetative annuals. Ethephon application resulted in fewer flowers for 16 of the 27 species treated, though the magnitude of effect varied across species as well as among cultivars within a species. For example, although flower number of 'Colorburst Red' calibrachoa (Calibrachoa Xhybrida) was unaffected by ethephon, foliar sprays containing $1000 \mathrm{mg} \cdot \mathrm{L}^{-1}$ ethephon applied to 'Liricashower Rose' calibrachoa resulted in 47 fewer flowers per plant compared with untreated plants. In another study, Starman and Williams (2000) reported that spraying 500 or $1000 \mathrm{mg} \cdot \mathrm{L}^{-1}$ ethephon solutions on common fanflower (Scaevola aemula 'New Wonder') delayed flowering by 8 or $11 \mathrm{~d}$, respectively, compared with control plants. Plant width was also suppressed by up to $77 \%$ compared with control plants when ethephon was applied.

The GI of each streptocarpus cultivar was affected differently by ethephon applications (Table 3 ). Increasing the concentration of ethephon up to $1000 \mathrm{mg} \cdot \mathrm{L}^{-1}$ suppressed the GI of 'Ladyslipper Blue Halo' by $15 \%$ for a single application $\left(R^{2}=\right.$ 0.23 ) and $22 \%$ for multiple applications $\left(R^{2}=0.49\right)$. Alternatively, ethephon did not affect the GI of 'Ladyslipper Deep Blue Vein' or 'Ladyslipper Red Rose' (data not shown). Though the GI was less for 'Ladyslipper Blue Halo' plants treated with ethephon, even the plants most affected by ethephon were still marketable. We believe that streptocarpus flowers are not significant sinks during production, since we observed little difference in GI regardless of flower number. Therefore, using ethephon to prolong the period of vegetative growth may be more useful to improve crop sanitation than for reallocating carbohydrates to vegetative growth instead of flower production.

We observed no phytotoxic effects of ethephon applications, aside from flower bud abortion. However, in a few instances, we observed two or three leaves growing on the terminal 
end of a peduncle of the inflorescence or phyllady. This was not widely observed across all ethephon treatments, including ethephon concentration and number of applications, or cultivars (data not shown). This phenomenon only occurred on plants treated with ethephon.

While the use of ethephon on flowering annual and perennial bedding plants has been reported, we found no reports of the effect of ethephon on the growth and flowering of streptocarpus. However, Callesen and Adriansen (1983) and Miller (2005) studied the impact of ethephon foliar sprays on growth and flowering of sylvan seemannia (Seemannia sylvatica) and achimenes or hot water plant (Achimenes hybrids), which are other plants in the family Gesneriaceae. Callesen and Adriansen (1983) quantified the response of sylvan seemannia to foliar applications of solutions containing $0,1000,2000,4000,8000$, or $16,000 \mathrm{mg} \cdot \mathrm{L}^{-1}$ ethephon. Plants treated with $1000 \mathrm{mg} \cdot \mathrm{L}^{-1}$ ethephon flowered 4 to 6 weeks later than untreated plants, while plants treated with $16,000 \mathrm{mg} \cdot \mathrm{L}^{-1}$ ethephon flowered 14 weeks later. Additionally, height of sylvan seemannia was increasingly shorter than untreated plants as ethephon concentration increased. Miller (2005) applied solutions containing 0 , 250,500 , or $1000 \mathrm{mg} \cdot \mathrm{L}^{-1}$ ethephon one, two, or three times to achimenes 'A09', 'A16', and 'A23'. The percentage of plants flowering at the end of the experiment ranged from $93 \%$ to $51 \%$. Untreated plants flowered 7 weeks after treatments were initiated, while flowering of achimenes treated with 500 or $1000 \mathrm{mg} \cdot \mathrm{L}^{-1}$ ethephon three times was delayed up to 11 weeks compared with untreated plants.

We estimated the PGR cost for a foliar application of solution containing $1000 \mathrm{mg} \cdot \mathrm{L}^{-1}$ ethephon applied at $0.5 \mathrm{gal} / 100 \mathrm{ft}^{2}$ using PGRCALC (Krug and Whipker, 2010). Using the average price for the cost of a commercial ethephon product it would cost $\$ 10.23$ per spray application per $1000 \mathrm{ft}^{2}$ of bench space. Based on these calculations, we believe that the PGR and application labor costs associated with applying ethephon to prevent premature flowering are minimal when compared with the potential labor costs to manually remove flowers for $\approx 4-5$ weeks while plants are growing to a marketable size.

\section{Conclusions}

Ethephon applications delay streptocarpus flowering while having a minimal impact on the quality of finished, marketable plants. Based on our research, applying foliar sprays containing $1000 \mathrm{mg} \cdot \mathrm{L}^{-1}$ ethephon aid delaying flowering of 'Ladyslipper' streptocarpus cultivars and, therefore, minimize the use of hand labor for removing flower stalks before plants have reached a marketable size. Greenhouse producers will want to perform trials to evaluate the effectiveness of ethephon sprays with streptocarpus cultivars they use under their specific greenhouse environment and culture.

\section{Literature cited}

Barrett, J. 2001. Mechanisms of action, p. 32-41. In: M.L. Gaston, P.S. Konjoian, L.A. Kunkle, and M.F. Wilt (eds.). Tips on regulating growth of floriculture crops. OFA Serv., Columbus, OH.

Callesen, O. and E. Adriansen. 1983. Development of rhizome-like shoots in Gloxinia sylvatica (HBK) Wiehler treated with ethephon. Sci. Hort. 21:85-92.

Cavins, T.J., B.E. Whipker, W.C. Fonteno, B. Harden, I. McCall, and J.L. Gibson. 2000. Monitoring and managing $\mathrm{pH}$ and EC using the PourThru extraction method. North Carolina State Univ. Hort. Lflt. 590.

Dole, J.M. and H.F. Wilkins. 2005. Floriculture: Principles and species. 2nd ed. Pearson Prentice Hall, Upper Saddle River, NJ.

Ebert, V.F. and G.A. Ebert. 1984. The miracle houseplants. Crown Publ., New York, NY.

Glady, J.E., N.S. Lang, and E.S. Runkle. 2007. Effect of ethephon on stock plant management of Coreopsis verticillata, $\mathrm{Di}$ anthus caryophyllus, and Veronica longifolia. HortScience 42:1616-1621.
Hayashi, T., R.D. Heins, A.C. Cameron, and W.H. Carlson. 2001. Ethephon influences flowering, height, and branching of several herbaceous perennials. Sci. Hort. 91:305-323.

Hilliard, O.M. and B.L. Burtt. 1971. Streptocarpus: An African plant study. Univ. Natl. Press, Pietermaritzburg, South Africa.

Jeong, K.Y., B. Whipker, I. McCall, and J. Frantz. 2009. Gerbera leaf tissue nutrient sufficiency ranges by chronological age. Acta Hort. 843:183-190.

Krug, B. and B. Whipker. 2010. Using the PGR calculator. Greenhouse Grower 28(7):44-45.

Krug, B.A., B.E. Whipker, I. McCall, and B. Cleveland. 2010. Geranium leaf tissue nutrient sufficiency ranges by chronological age. J. Plant Nutr. 33:339-350.

Miller, C.T. 2005. Physiological studies of Achimenes. MS Thesis, Cornell Univ., Ithaca, NY.

Möller, M. and Q.C. Cronk. 2001. Evolution of morphological novelty: A phylogenetic analysis of growth patterns in Streptocarpus (Gesneriaceae). Evolution 55:918-929.

Moore, H.E., Jr. 1957. African violets, gloxinias, and their relatives: A guide to the cultivated gesneriads. Macmillan, New York, NY.

Starman, T.W., M.C. Robinson, and K.L. Eixmann. 2004. Efficacy of ethephon vegetative annuals. HortTechnology 14: 83-87.

Starman, T.W. and M.S. Williams. 2000. Growth retardants affect growth and flowering of scaevola. HortScience 35: 36-38.

Uhl, R. 2012. Streptocarpus ladyslippers series. Greenhouse Product News 22(7): 60-61.

Whipker, B.E., T.J. Cavins, J.L. Gibson, J.M. Dole, P.V. Nelson, and W. Fonteno. 2011 a. Water, media, and nutrition testing, p. 49-66. In: J. Nau (ed.). Ball redbook. Vol. 2: Crop production. 18th ed. Ball Publ., West Chicago, IL.

Whipker, B.E., I. McCall, and J. Latimer. 2011 b. Growth regulators, p. 95-10. In: J. Nau (ed.). Ball redbook. Vol. 2: Crop production. 18th ed. Ball Publ., West Chicago, IL. 